\title{
TRADITION OF CHRISTMAS YOUTH GATHERINGS AT THE VISHERA RIVER (KOMI REPUBLIC)
}

\author{
Galina Savelyeva
}

Senior Research Fellow

Folklore Archive, Institute of Language, Literature, and History

Komi Science Centre, Russian Academy of Sciences, Russia

Email: galsav69@mail.ru

\begin{abstract}
The article deals with the tradition of Christmas youth gatherings within a narrow local tradition that exists at the Vishera River (a tributary of the Vychegda River, the Komi Republic). The structure of the research includes the following sections: the history of studying the ethnocultural specific character of the Komi at the Vishera; a combination of the circle dance and a game; some aspects of the existence of borrowed songs; merrymaking entertainment and disguises; and the transformation of the ritual (merrymaking of youngsters). Different stages of the existence of this ceremonial complex, which are historically determined, are represented: traditional, adolescent from the Soviet period, and the modern one.
\end{abstract}

Keywords: Christmas, Komi-Zyrians, song folklore, youth gatherings

\section{INTRODUCTION}

The subject of the research is the tradition of Christmas youth gatherings, i.e., merrymaking within one of a group of narrow local Komi traditions. Defining the term 'merrymaking', Tatyana Bernshtam (1978: 65-66) singles out three main components of the term: 1 ) a type of the youth festival that is held in summer and winter periods of the calendar year; 2 ) doing a circle dance and singing specific songs, in which young men and women take part; the merrymaking composite may include traditional games, such as 'race-and-catch', etc.; 3) dominance of the wedding and matrimonial topic ('pre-wedding composite'). These three aspects can be complemented by the fact that merrymaking was a communal activity and a ritual action, in which all age and sex groups would take part, and each of them had its own part to play (spectators, singers, leaders, those in disguise, participants in rituals and performances, etc.). 


\section{HISTORY OF RESEARCH ON THE ETHNOCULTURAL SPECIFIC CHARACTER OF THE VISHERA KOMI}

The Vishera River (Bucep in the Komi language) is the right tributary of the Vychegda River (Эжва). Its territory is a part of the Kortkerossky District in the Komi Republic and includes the villages of Nivshera (Одьљ), Bogorodsk (Висер), and Bolshelug (Ыджыдвидз) with their adjacent settlements. Ethnographers associate the beginning of the formation of the Upper Vychegda group of the Komi-Zyrians with the history of settlement of the banks of the Vishera. The first records date back to the second half of the fifteenth century and contain information about the first settlers from the Vym River (Елва). The distinctive character of this tradition is highlighted in a number of ethnographic and folkloristic studies (Zherebtsov \& Lashuk 1958; Teryukov 1983; Panyukov 2004; Panyukov \& Savelyeva 2006: 274-277; Lobanova \& Rassykhaev 2013, $2016,2017)$. The linguistic research also bears witness to the dialectally specific character of the speech of the population of this area, which is distinguished as a separate subdialect of the Upper Vychegda dialect of the Komi language (Sorvachova \& Sakharova \& Gulyaev 1966: 7, 9).

Field research in Nivshera, Bogorodsk, and Bolshelug has almost a centuryold tradition. The first folklore records in this area were made by Victor Savin and Pavel Anisimov in 1926. The description of their trip is represented in one of the feature articles of Savin (1926). In 1938-1939, Ivan Osipov was working at the Vishera River. Some examples of song and fairy-tale folklore were recorded by him in their sound version. ${ }^{1} \mathrm{~A}$ collection of stories called Висер вожса сььланкыьвля да мойдкььвљяс (Songs and Fairy Tales of Vishera Vicinity) (Osipov 1941) was published on the basis of the material collected in the course of field research. In 1954, the songs of Bogorodsk were recorded by Sergey Piatiev (Kuznetsov \& Lobanova 2014: 77-78).

While the records made in the first half of the twentieth century were limited to separate folklore samples, the subsequent field research involved a purposeful frontal collection of field material. In 1962-1964, studies of the Vishera tradition were made by Prometey Chistalyov and Galina Muravyova. ${ }^{2}$ In terms of the amount of recorded sound material, their field research has been the most large-scale and fully representative of the song tradition of the Vishera, without any kinds of presets with regard to the language-based selection of recorded material. The recordings of songs in Bogorodsk and Nivshera are also available in the linguistic material collected by the Estonian researcher Anu-Reet Hausenberg in 1968 (Kuznetsov \& Lobanova 2014: 79-80). In 1978, a group of researchers conducting linguistic and folkloristic field research, with the participation of Yuri Rochev and Vladimir Lyashev, was working in the villages of 
Nivshera and Lymva. ${ }^{3}$ In 1994-2000, a number of field studies were conducted by Anatoly Panyukov and Galina Savelyeva. ${ }^{4}$ In 2010-2016, the Vishera tradition was researched by Liudmila Lobanova and Aleksey Rassykhaev.

At present, Nivshera holds a unique position on the cultural map of the republic. Some of the elements of calendar rituals are still alive here and exist within the living tradition till this day. The traditional song repertoire is also preserved, although not nearly to the extent as full as compared with the material dating back to the middle of the past century. Here Christmas merrymaking took place up until the 1960s. Then, after a short break, the festivities were resumed at the village community centre, with all of the main action elements being preserved. In recent years, Christmas merrymaking is mainly associated with the activities of the local folklore band 'Sipertas' (headed by Maria Popova).

\section{COMBINATION OF A CIRCLE DANCE AND A GAME}

The main content of Christmas merrymaking at the Vishera is related to acting out the scenario involving a circle dance and a game. The songs that were sung within that scenario (рӧштво сьыланкьвъяс 'Christmas songs') were widespread throughout Kortkerossky District. There were no other recordings concerning such a strict confinedness in any other areas. The same thing can be said about the geographic range of the existence of the name of the merrymaking process - чивильтэл, which was only common in Bolshelug, Bogorodsk, and Nivshera. The term чивильтэл is related to the first rota named Чивиль-чивиль воробей 'Chivil'-chivil'5 the sparrow', which was sung while the participants were forming a circle.

The scenario is acted out in the following sequence: circle dances, 'braiding and unbraiding the rope', the 'row-to-row' circle dance, refrain songs (that helped to find matches, see below).

When singing in a circle, the participants simply walked in circles, stamping their feet and holding their hands. In addition to the song Чивиль-чивиль воробей, the songs sung in a circle also included Здравствуй милова 'Неllo milova ${ }^{6}$ ' (milova < darling), Изу лесу 'From the forest', Я вечора молодова 'I'm young in the evening', and others. These songs have a relaxed rhythm and the strophics typical of circle songs, which consists of four verses corresponding to four strings of notes (in the type of AABB). In musical terms, the second part of the verse has a faster pace, which is achieved by splitting 1/4 into 1/8.

According to the description of Christmas gatherings in Bogorodsk, which was given on the basis of the performance acted out at the request of the collector, songs sung in circles were divided into fast and slow ones. 
“Куил луннад вед мыйке вӧлі сьылам. Майбыр, гажид вӧлі. Питшегад пирог либе шаньга сюйиштан да котэртан войпук вылад. Детинаяс вӧлі пять кӧпеек сетэны керкатэ войпукні медалігад. Сэсся рытыыьбыц сьылам да ворсал. Кор бурлакъястэ мичаджик ныькед сьылэдан, любеәд вӧлі...” С этили словали певиць мои поднялись с мест и встали в круг. У. Ф. Калистратова запела "Чивиль" и пошли по кругу. А затем последовали "Я на два", "Чипан ладэн" [не переводится - G. S.], "Я вечера молодова”. Все это пели спокойно и плавно, ходили по кругу. Но вот запели "Я скажу, скажу", все остановились и начали петь быстрыл телпол, при этол топали ногали и похлопььвали в такт рукали. "Вдоль по бережку" так же исполнили, а зател запели "Заплетой”. Стали "плести веревку".7

'Within three days something was sung. It was fun. You would put a pie or a shan'ga $a^{8}$ in your bosom and run off to a party. Lads would pay five kopeks to rent a house, and we would play and sing all night. It was such a nice thing when you matched a young man with a beautiful girl through a song...' With that my singers rose up from their places and stood in a circle. U. F. Kalistratova started singing "Чивиль" and we started moving in circle. The first song was followed by "Я на два", "Чипан ладэн" [untranslatable - G. S.], “Я вечера молодова” [I’m young in the evening]. They sang all of those songs very peacefully and smoothly and walked around in circles. But when they started singing "Я скажу, скажу” [I will tell you], everyone stopped and started singing fast, stomping their feet and clapping their hands in tune. Then they sang "Вдоль по бережку" [Along the coast] and "Заплетой” [Braid it]. And they started 'braiding a rope'.

Fast songs, in addition to the aforementioned "Я скажу, скажу", also included "Под горою Ваня топится" (Ваня < баня 'sauna'; The sauna is heated at the bottom of a hill), "Мишчую да миленькой" (misspelled, untranslatable), "Старечник" (Old man), etc.

The next type of a circle dance is 'braiding a rope', which was danced to the tune of "Заплетай". The dancers held hands. The first pair of people at the end held their hands up high and made the 'gates' through which all other dancers had to pass, starting from the furthest end of the line. Then the next pair of people made the 'gates', and so on, until there was a live spiral: dancers stood one after another with their right hand on the left shoulder and holding the left hand of a person standing at the back, while the left hand was stretched forward onto the left shoulder of a person standing at the front. Then the dancers started 'unbraiding the rope' while singing the song "За гур девица" (A girl 
from behind the mountains). The song was repeated for every single dancer in the circle dance:

“Заплетой” in the beginning, and then we would sing this song as many times as was needed, let it be one hundred or two hundred people. /.../ Then we started singing 'За гур девица', until the game stopped [until all of the dancers in the circle were 'unbraided' - G. S.]. ${ }^{9}$

In addition to the traditional designation of this choreography as 'braiding/ unbraiding the rope', a peculiar terminological adaptation of 'locking/unlocking' was recorded in Nivshera:

We would come in a circle and sing “Заплетай”. If there were thirty people, we would sing it thirty times. You walk in a circle and then come nearer, then they would lock you in, walking around the whole time. Then they would lock another one in. And take by a shoulder. Then they would sing it again and lock another one in, singing “Заплетай” the whole time. Then, when everyone was 'locked in', they would walk in a circle, about three times. Then they would start unbraiding. "Загур девица" - the unbraiding song. They would unlock thirty locks, walking around in circles and dancing. ${ }^{10}$

Then there was a circle dance to the song "Ми пе тавун кӧдзалал, кӧдзалал” (Today we were sowing, sowing), which is an adaptation of the translation of the song 'We were sowing millet', which is widespread in the Russian tradition (Krasnopolskaya 1977: 135, 136; Bolonev \& Melnikov 1985: 103, 104, and others). The dancers would stand in two lines opposite each other. The lines approached each other and then came back. The song was sung in the form of a dialogue with the refrain "Ай ладy, ладy" (untranslatable). In the first part, the topic of sowing was dealt with in the form of questions and answers:

- Мыцйӧн жӧ да кӧдзалад, кӧдзалад,

Ай ладу, ладу, льєйӧн жӧ, мьийӧн жӧ?

- Вӧӧясӧн пӧ кӧдзалал... ${ }^{11}$

- Kыıсь бара пӧ вӧӧясыс?...

- Вӧӧястӧ ли куталам...

- Мыйӧн же ті куталад?...

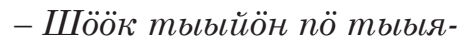

лал...

(Osipov 1986: 41)
- What are going to use for sowing, sowing?

Ai ladu, ladu, what are you going to use?

- We are going to use horses ...

- Where will the horses come from? ...

- We will catch the horses ...

- How will you catch them? ...

- We will catch them with a silk net ... 
Then the singers would sing about sowing the millet they have bought. Then about buying and selling girls. One of the parties wanted to buy a girl, and the other one would set the price: the 'average' girl cost one hundred roubles, 'another' one - one thousand roubles, and the 'furthest' one - two hundred roubles. In the end, a girl would move from one line (party) to the other:

- Миян пӧ ныbы соді...

- Now we have more girls ...

- Миян пӧ тавун ныьь чині... - Now we have less girls ...

(Osipov 1986: 42)

In the Soviet period, the dancers in the circle were divided into 'collective farmers' and 'communists'. The song was also adapted respectively:

- Комлунистьяс, дами тіян - Communists, we are coming to дінэ волал!... you! ...

- Колкозникъяс, мыйӧн жӧ ті - Collective farmers, how are you локтаннід?...

- Колмунистуяс, ми вӧд вӧвдясӧн локтал...

- Колкозникъяс, кутшӧл нӧ же вӧвбясьд?...

- Колмунистьяс, вӧвъясіс тшая кокась...

- Колкозникъяс, да лиянлі

ӧти морт колэ... coming? ...

- Communists, we are coming by horses ...

- Collective farmers, what kind of horses do you have?...

- Communists, with the white brush

- Комлунистьяс, да кодэс же mi босьтаннід?...

- Колкозникбяс, да миянлі этія колэ...

- Миян полкніл чині-чинічині...

- Миян полкніл соді-содіcoдi...

- Миян полкніл шолаясшолаяс... ...

- Collective farmers, we need one person ...

- Communists, who do you take?

...

- Collective farmers, we need this one ...

- That's one up for our side

...

- That's one down from our side

...

- There's a sour one up for our side ... $^{12}$

After the part with the circle dance, couple-making songs pöштво сььлӧдчанкьвъяс were sung: "Сирчунь-бирчунь” (untranslatable), “Ылььньллььн тшыьн тшыналӧ” (Far, far away the smoke is smoking), "Bьлльысь пӧжӧмӧй да Mатрёнаӧй"(Newly-minted Matryona), etc. Couple-making songs are one of the types of game forms of a youth wedding - marrying off through 
a song (Kaneva 1998: 112). The main attribute of this group of song and game folklore is naming a specific boy and girl by their name and patronymic. Merrymaking participants stood in a circle, and the pair that was sung about stood in the centre, or everyone was sitting in their places, and the pair was standing in front of everyone and dancing to the song:

They would be dancing in the centre of the circle, no matter what, anything they could. Sometimes paturlikas'öny [literally 'turning somersaults, cavorting'], the lads. And the girls were dancing around, just any way they could. ${ }^{13}$

At the end of the song, the boy and the girl would hug and kiss each other:

They sang them into couple, then another / pair/. If they liked each other, they would hug each other, if they didn't, they wouldn't. ${ }^{14}$

The young man had to kiss the girl; they would step away into the corner and hug each other. Or do nothing. Just give each other a half-hug. ${ }^{15}$

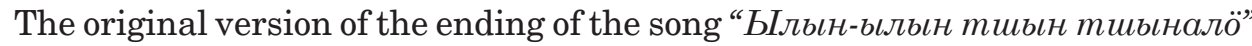
was recorded in Nivshera. Among the Komi, this song was universally widespread:

Ыльц-ьлььн тшын тшыналӧ, Far, far away the smoke is smoking, Матьıн-латьљн дуб дубалӧ, Дуб улас нёль кер,

Нёль кер улас нёль кор,

Нёль кор улас нёль тусь,

Öти тусь - Kamя,

Мӧд тусь - Микулай, Nearby the oak is growing bard, There are four logs under the oak, There are four leaves under the four logs, There are four berries under the four leaves, One berry is Katya,

Койлӧд тусь - Матвеевна, Another berry is Nikolai, Нёльӧд тусь - Елизарович. The third berry is Matveevna, The fourth berry is Yelizarovich.

The Nivshera adaptation continues:

Катясӧ да Микулайсӧ

Гидӧ сюял - игналал, Идзас волес вольсалал да, Асылӧдзысс сэн видзалал. ${ }^{16}$
We will put Katya and Nikolai into a cowshed and lock them in, We will spread out a straw mat, And keep them there until morning. 
While that song was sung, everyone sat, and the pair which was sung about walked around, holding each other's hands and hugging each other. Then they would ask a boy and a girl: 'Will you go into a cowshed?' If the boy and the girl liked each other, they would walk away, hugging and kissing. If they did not, they would sit back down.

\section{SOME ASPECTS OF THE EXISTENCE OF BORROWED SONGS}

Festive gatherings of the Komi youth, just like the complex of Christmas rituals on the whole, date back to the northern Russian tradition. This is why the majority of the songs sung during merrymaking is represented by borrowings

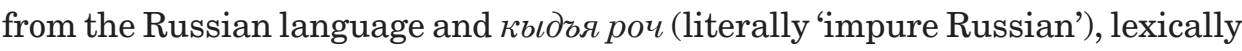
misspelled units. ${ }^{17}$ The preservation of the Russian-language borrowings in calendar rituals is typical of all Komi traditions. The trend of conserving the songs assigned to the ritual is accompanied by specific mechanisms of language comprehension and secondary etymologization of borrowed texts. Thus the beginning song 'Chivil'-chivil' the sparrow' gets an original ending:

Ешиӧ жӧник тотара,

Тотара ли понтара

Ешё сель четверу,

Четверу ли шестою.
Still the groom totara,

Totara or pontara

Seven more or four, four or six.

The emergence of a number series понтара (apparently from Russian полтора 'one and a half'), сель (seven), четверу (four), шестою (six) is related to the idea of structuring and distinguishing a youth group (the main participants of merrymaking), which is engrained in a circle dance. For comparison, we could describe an ӧктысян 'gathering' circle dance that is widely spread both among the Russians and the Komi. To the accompaniment of certain songs, a young man selected a girl, and a girl selected a young man, etc., until a large circle was gathered. The count in the text as well as the actional phasing of gathering were aimed at organizing the youth space for merrymaking. Apparently this is why the song 'Chivil'-chivil' the sparrow' was sung at the beginning of the circle dance and the game part, and a derivative term made from the name of the opening song entrenched itself as a denomination of the entire song and game complex - чивильтӧли.

In their essence and content, the songs sung in a circle dance have something in common with lyrical long drawn songs. In spite of linguistic deformation, it is quite easy to single out key images in them, through which the topics of 
parting, loneliness, unhappy marriage, etc. are actualized. For example, in the song “Здравствуй милова" (Hello, my dear), the subject matter determined the following lexical stream: to no one, my dear - under the cradle in tears all alone - without me - without you - without you, my last single friend. This diverse imagery is united by the meaning of the absence of someone or something. Below is a text with the approximate reconstruction:

\begin{tabular}{|c|c|c|}
\hline Здраствуй милова... & Hello, my dear... & \\
\hline Здраствуй милая & Hello, my darling... & \\
\hline корошая моя... & The black-browed... & $<$ black-browed \\
\hline Черной бравой... & The black-browed, & \\
\hline Чернобравоя & the good one... & \\
\hline порядошная... & Yus' kok to no one... & $<$ oh so; yus' kok \\
\hline Юсь кок некому... & Yus' kok to no one, & literally 'swan \\
\hline Юсь кок неколу & my dear... & foot' \\
\hline голубушка моя... & Sgolov'yushki & $<$ sgolovyitse (pil- \\
\hline Сголовьюшки... & Sgolov'yushki under & low) sunk in tears \\
\hline Сголовьюшки потан & the cradle, in tears... & $<$ blanket \\
\hline улььн во слезах... & I'm lying down all on & became covered \\
\hline Один я лечь... & my own... & with hoarfrost \\
\hline Один я лечь три зачел & I'm lying down all on & \\
\hline девала... & my own, why three... & \\
\hline Три гӧлубчик... & Three, my dear... & $<$ will fondle and \\
\hline Три гӧлубчик три & Three, my dear, & caress \\
\hline ласкачот без меня... & three laskachot & \\
\hline Без тебтя... & without me... & \\
\hline Без тебъя мой друг & Without you... & \\
\hline последний колостой... & Without you, my last & \\
\hline Здраствуй милова... & single friend... & \\
\hline Здраствуй милая & Hello, my dear... & \\
\hline хорошая моя. ${ }^{18}$ & Hello, my darling. & \\
\hline
\end{tabular}

A dramatic example of linguistic re-thinking of a text in the Russian language is the formula потан ульн 'in tears'19 'under the cradle in tears' from the original 'the pillow sunk in tears'. The emotional plan of the Russian adaptation (night sadness, melancholy) in the Vishera adaptation is transformed into an image of a woman crying near the cradle, which makes the aspect of the heavy burden of a woman even more vivid in terms of its actualization. 
The outcome of this phonetic transformation is one of the formulas in the song "Изу лесу" (From behind the woods), which stands out against the background of lexically unsubstantiated string-like arrangements, i.e., война вэли 'waged a war' (the original version was, apparently, 'beating-thrashing soundly'). The following comment is very illustrative of the significance of the motif of war that emerged as a result of transformations: “Изу лесу” was sung by women, including young women, whose men were at war, they danced with zest. Not only us, the little ones, but women, too. When they came home from work in the evenings.' 20

Along with the topic of parting, these texts also include the topic of an encounter and the related motif of the reunion of a boy and a girl. Some adaptations of the song “Здравствуй милова" run on and end with a 'kissing' formula: 'kiss three times'.

In the song "Изу лесу" the closing formula includes the verbal stream that is associated with the motif of walking in circles: we walked - we walked aroundwe came back - we walked in circles. From that perspective, this circle song can be correlated with the circle dance, in which an interchangeable pair to walk around - to stroll is included in the scheme: looking for a mate - finding a mate-consolidating the pair (for example, the storyline of a tsar's son is very popular both in the Russian and the Komi traditions).

Couple-making songs were evolving independently both in terms of linguistics and folklore-poetics. The two opposite ends can be marked with regard to formal and semantic organisation of these texts. There are songs that constitute deformed texts, in which it is not possible to distinguish a conceptual core even at the level of individual words. In this context, the names themselves are endowed with distinct meaning, by means of saying of which the process of 'marrying off' takes place. On the other hand, if we compare couple-making songs with other groups of game songs, it is the former that incorporate the concentration of the main block of texts in the Komi language. Moreover, the majority of them do not result from the transfer of individual Russian plots into the Komi language. Ritual semantics, conceived and comprehended within the context of tradition, have transgressed into poetic forms generated by culture. Some of them are stable and widespread adaptations, while the improvisatory beginning based on folklore universals is incidental to others. 


\section{MERRYMAKING AND DISGUISE-WEARERS}

Merrymaking was associated with amusement and entertainment which, similar to the Russian tradition, were meant for newcomers and were of testing and dedicative nature (Morozov 1998: 114, 115). One of them was called кӧзa льсьтӧл 'milking a goat'. One of the girls dropped to all fours, another one sat down by her side, stretching her legs under the body of the 'goat', and started miming the process of milking. Then the 'goat' would collapse on the 'milkmaid' who fell on her back with her legs up in the air. ${ }^{21}$ Another similar type of entertainment was Мӧсква видзеднь 'seeing Moscow' and it consisted in the following: ash was poured into a 'spyglass' made of paper, which was covered at one of the ends. A newcomer was asked whether he or she wanted to see Moscow, and after they had agreed and looked into the 'spyglass', ash poured into their eyes. ${ }^{22}$

Disguise-wearers were traditional participants in merrymaking in Nivshera. According to available records, they dressed up as a 'cock' (петук) and a 'sieve head' (пож юр). Two or three people dressed up as cocks entered a room: they put on a sheepskin coat and thrust a fire iron through the sleeve, which was used to 'peck' other people in the room. The sieve head was an anthropomorphic character: one person held a shoulder pole with a sheepskin coat on it above their head, and they also held a sieve up high with a headscarf on it. The disguised person was beneath the coat, the shoulder pole represented their arms, and the sieve was the head. Their main task was to frighten the players. Informants compared the sieve head to the Leshy. ${ }^{23}$

\section{TRANSFORMATION OF THE RITUAL MERRYMAKING OF THE YOUTH}

On the one hand, the field research data from recent years (since 1994) give an idea of the organizational aspects of merrymaking, and on the other hand, allow to trace the changes that were taking place in the context of the tradition of Christmas merrymaking throughout the twentieth century.

Information about merrymaking, which can be correlated with the data collected during field research in the middle of the last century in terms of completeness and integrity, was recorded in 1997 and 2000 from female inhabitants of Nivshera, who were able not only to re-create the set of relevant rituals with ease, but also constituted a sample of the 'natural' singing group. ${ }^{24}$ 
In the reports provided by other performers, Christmas merrymaking in most cases was represented as youth (children's) gatherings. The informants born in 1928-1934 mainly described the merrymaking in which they had taken part (in 1940-1950). Some informants pointed out that they were the last generation that still had чивильтӧл-type gatherings. The participation of youngsters in merrymaking was sporadic, and the main active participants were children aged 10-14. In view of a number of some external factors, the youth' merrymaking of the time was related to living in logging barracks and was held under its own inertia.

We would even come together to enjoy chivil'töm merrymaking at logging camps. We would gather together, equals in age, come into one barrack, then into another one. We were quite grown-up by that time. ${ }^{25}$

To organize merrymaking for children, usually a house was rented from lonely people or from families with many children, i.e., from those who were living in poverty and needed money. Both girls and boys took part in merrymaking:

After lunch we would start looking for a house: we would be asking our fellow villagers, one after another, both boys and girls. ${ }^{26}$

Mothers took active part in preparing their children for merrymaking:

Mother would bake pies, and we took them to chivil'töm- merrymaking. ${ }^{27}$

Mother would send us away saying: 'You must not go empty-handed to the chivil'töm -gathering'. We brought different stuff with us, someone brought pies, others brought sugar. Then we would sit all together and drink tea. ${ }^{28}$

At youth gatherings, the traditional song and circle dance repertoire was invariably acted out, while games were of the highest priority. It is on games that the informants placed the greatest focus in the majority of descriptions:

First of all, we sang "Чивиль" and stood in a circle. Then we played other games: “Кума-кула”, “Гьр юр”, until late. ${ }^{29}$

We walked to ‘чивильтны' (played чивиль). / ... / Children played “Kyлnкy.nа", hide-and-seek. ${ }^{30}$

We paid with pies and shan'gas for a house. Equals in age, we would gather together, from twelve years old. And older children would also come. We played 'чивиль' [the circle dance part - G. S.], then we played: “Телеббон” [Telephone], "Гььр юр”. Girls would put on beautiful dresses, shawls, and rush off to 'чивильтны'. ${ }^{31}$ 
Rules of the games mentioned above:

"Гьр юр"(Mortar-head). The game leader was covered with something. One of the players tapped or pushed him, and everybody asked: 'Тыр юр, код воліс?' (Mortar-head, who came here?) If the lead singer got it right, the player who pushed him replaced him.

The games "Кула-кула" (untranslatable) (and “Жель дзебан” (Hiding a chip)) are adaptations of the 'ring'-type game. According to the rules of the first game, players stood in a circle, and the blind-folded lead player was placed in the centre. Then some item was hidden in the hands of one of the players. After the question 'Kuma-kuma, who has it?', the lead player had to guess who was holding the hidden item. According to the rules of the second game, everyone was sitting, and one of the players would put a 'chip' into the hand of another player discreetly. The lead player had to guess who had the chip.

“Дзебсясян" (Hide-and-seek). This game was played in the house. The younger lead players paired up, while the older ones were on their own.

The game "Kyтасел" (Play tag) was also included in the process of Christmas merrymaking. This is how it was played: Everyone was standing in a circle; two people were standing outside of the circle, and one of them was chasing the other, trying to catch him or her; the person being chased could 'save' himself or herself by stepping in front of one of the players, after which this particular player started running away from the lead player.

The scenario of youth merrymaking also includes such a significant action element as matching pairs. Couple-making songs are sung during pair-matching, but their purpose changes, i.e., it transforms from consolidating potential brides and grooms in pairs to 'playing adults' of some kind, in which a 'funny' part was put in the forefront:

We would sing couple-making songs just for fun, if we knew who was a match, we sang them, and if we didn't, we would sing someone on purpose. ... We were teasing the lads if we knew who they were friends with. We had known many of them since childhood. We would sing all of the lads matching them with girls. ${ }^{30}$

We would sing all of the lads, who will get whom. ${ }^{31}$

A similar attitude to adult 'genres' is evident in Christmas youth fortune-telling:

We wrote the name of the groom and some other words on small pieces of paper, roll them up, walk out in the street and scatter them around, and then we looked what each one of us got. And we laughed a lot. We were twelve then. ${ }^{33}$ 
The presence of spectators was a must at merrymaking. As a rule, these were 'old women' who just watched and sang along as well as young married women who could also take part in the game. The participation of other sex and age groups in merrymaking is related to one of the most interesting innovations, i.e., saying prayers and singing sacred songs alternating with games:

- Where we were celebrating, in the same place, there were our mothers, they were not old yet, well, my age [about 67 years - G. S.], and they were saying prayers. They didn't sing those songs [merrymaking - G. S.], it was a sin for them. They were very, very religious, Orthodox, they sang many prayers.

- Christmas prayers?

- Yes, Christmas prayers, and many other prayers.

- In the same house?

- Yes. They came to watch, and when we got tired, they started singing prayers. They would milk cows, and if they had no other chores, they would come to a party in the evening. ${ }^{34}$

The prayers that were said, festive troparions, and other sacred songs represent the standing local repertoire, which is performed on holy days in honour of family icons, which are also celebrated today.

The replacement of youth Christmas merrymaking with adolescent merrymaking in Nivshera is one of the examples when new factors were mainly caused by age shifts. While the participants in traditional festive and everyday gatherings were unmarried youngsters aged 16-22, in adolescent gatherings their age dropped down to 14 years old.

Adolescent Christmas merrymaking replaces youth merrymaking, keeping the communal nature of the event. It is this particular attribute that predominates, which blurs the matrimonial idea/aspect of merrymaking. The borderline age-related status (not children yet, but not 'brides' and 'grooms' either) becomes determinant while re-thinking the role of merrymaking in the life of a group of people as a single composite of worldview and ritual perceptions: the song and game scenario is acted out in full, but with limitations that are relevant to age; the meaning of merrymaking as a prenuptial youth game is changing; it becomes possible to incorporate a stock of prayers from Orthodox holidays into merrymaking.

The conservation of rituals and certain ritual elements in children's/adolescent environment is one of the means of preserving and transforming traditional culture. It should be pointed out that in the village of Poztykeros in the same district the opposite process took place: the informants born in 1912-1916 point 
out that 'old women' gathered together at Christmas, while the youth went to the club. Consequently, two different forms of celebrating Christmas co-existed: the merrymaking that took place in accordance with the traditional scenario, the main participants in which were 'older women', and the new form of going to the club. This kind of status refocusing on Christmas merrymaking has led to a complete disappearance of the tradition.

\section{CONCLUSION}

In view of social and political conditions of the Soviet period, rural cultural life in the twentieth century mainly focused around local community centres (clubs). Throughout almost the whole area, the traditional festive and calendar cycle has been replaced with a set of rituals which were new both in content and in form. By contrast, Nivshera is a rare exception. Christmas merrymaking has not only been preserved in the memories of local old-timers, but also occupied a strong position in the system of Soviet celebrations. The chronology and amount of the data collected during field research allow to imagine different stages of existence of this set of rituals, which can be substantiated from the historical perspective: traditional, at logging camps, adolescent. At present, merrymaking is a trademark of the local folklore band and a living proof of the distinctive cultural character of the Vishera region.

\section{ABBREVIATIONS}

A - audio recording

$\mathrm{V}$ - video recording

SA Komi SC - Scientific Archive of the Komi Scientific Centre of the Ural Branch of the Russian Academy of Sciences

FDA - field data collected by the author

FA of SSU - Folklore Archive of Syktyvkar State University

FF of ILLH - Folklore Archive of the Institute of Language, Literature, and History of the Komi Scientific Centre of the Ural Branch of the Russian Academy of Sciences 


\section{NOTES}

1 Handwritten material by Osipov is archived at the Scientific Archive of the Komi Scientific Centre of the Ural Branch of the Russian Academy of Sciences: F.1. Op.11. D.36. Sound recordings are archived at the archive of sound recordings at the Institute of Russian Literature of the Russian Academy of Sciences.

${ }^{2}$ Material of Viservozhsky folklore field research (Scientific Archive of the Komi Scientific Centre: F.1. Op.11. D.244). Audio recordings are archived at the FF of ILLH (Kortkerossky collection).

3 The materials of folklore and dialectological field research collected in Kortkerossky District of the Komi Autonomous Soviet Socialist Republic (SA Komi SC: F.5. Op.2. D.233a). Sound recordings are archived at the FF of ILLH.

4 The material collected in 1994 is archived at the FA of SSU; materials from 1995 to 2000 are archived at the FF of ILLH (Kortkerossky collection).

5 Чивиль-чивиль is an onomatopoeic word which means the twitter of the sparrow.

${ }^{6}$ From this point on, in the names of the songs, the words and expressions that are untranslatable (misspelled) are put in italics.

7 Report by G.A. Muravyova and P.I. Chistalyov about a folklore field research in Storozhevsky District in the Komi Autonomous Soviet Socialist Republic (SA Komi SC: F.1 Op.11. D.244a. L. 260, 261).

8 Traditional pastry.

9 Recorded by G. Savelyeva in Syktyvkar in 1997, from the inhabitants of the village of Nivshera, E.M. Podorova, born in 1932, and A.S. Gabova, born in 1933 (FF of ILLH: V1108-8).

From this point on the texts are presented with word-for-word translation made by the author of the article. In some texts, there are individual lexical units in the Komi language in brackets.

${ }^{10}$ Recorded by Y. Rochev and V. Lyashev in the village of Nivshera in 1978 (SA Komi SC: F.5. Op. 2. D.233a, No. 100).

${ }^{11}$ From this point on, three dots in the text of the songs indicate the refrain.

${ }^{12}$ Recorded by G. Savelyeva in Syktyvkar in 1997, from the inhabitants of the village of Nivshera, E.M. Podorova, born in 1932, and A.S. Gabova, born in 1933 (FF of ILLH: V1108-9).

${ }^{13}$ Recorded by G. Savelyeva in Syktyvkar in 1997, from the inhabitants of the village of Nivshera, E.M. Podorova, born in 1932, and A.S. Gabova, born in 1933 (FF of ILLH: V1119-12).

${ }^{14}$ Recorded by A. Panyukov and G. Savelyeva in the village of Nivshera in 1999, from E.M. Podorova, born in 1932 (FF of ILLH: V1112). 
${ }^{15}$ Recorded by A. Panyukov and G. Savelyeva in the village of Nivshera in 2000, from A.S. Gabova, born in 1933, G.M. Larukova, born in 1922, E.M. Podorova, born in 1932, A.M. Zhizheva, born in 1928, and A.K. Larukova, born in 1929 (FF of ILLH: V1115-18, 20 ).

${ }^{16}$ Recorded by A. Panyukov and G. Savelyeva in the village of Nivshera in 1999, from A.S. Gabova, born in 1933, G.M. Larukova, born in 1922, E.M. Podorova, born in 1932 , A.M. Zhizheva, born in 1928, and N.V. Yeftene (Podorova), born in 1963 (FF of ILLH: V1112).

${ }^{17}$ The phenomenon of кьљдљs poч is dealt with in a number of articles by Anatoly Panyukov (e.g. Panykov 2003).

${ }^{18}$ Recorded by A. Panyukov and G. Savelyeva in the village of Nivshera in 2000, from A.S. Gabova, born in 1933, G.M. Larukova, born in 1922, E.M. Podorova, born in 1932, A.M. Zhizheva, born in 1928, and A.K. Larukova, born in 1929 (FF of ILLH: V1115-17).

19 The meaning of the expression потан улььн was provided by one of our informants, N.V. Yeftene (Podorova), born in 1963, and the handwritten text of the same song was also written down as told by her. The orthographic intricacies of the text in question allow to comment on the interpretative perception of this song.

${ }^{20}$ Recorded by G. Savelyeva in Syktyvkar in 1997, from the inhabitants of the village of Nivshera, E.M. Podorova, born in 1932, and A.S. Gabova, born in 1933 (FF of ILLH: V1108-7).

${ }^{21}$ Recorded by A. Panyukov and G. Savelyeva in the village of Nivshera in 2000, from A.K. Larukova, born in 1929 (FF of ILLH: V1115-21).

${ }^{22}$ Recorded from M.A. Popova, born in 1963, in the village of Nivshera (FDA).

${ }^{23}$ Recorded by A. Panyukov and G. Savelyeva in the village of Nivshera in 1999, from A.S. Gabova, born in 1933, G.M. Larukova, born in 1922, E.M. Podorova, born in 1932, and A.M. Zhizheva, born in 1928 (FF of ILLH: V1112).

${ }^{24}$ Aleksandra Stepanova Gabova, born in 1933, Glafira Matveevna Larukova, born in 1922, Ekaterina Matveevna Podorova, born in 1932, Aleksandra Matveevna Zhizheva, born in 1928, Anna Kirillovna Larukova, born in 1929, Nina Vassilyevna Yeftene (Podorova), born in 1963.

${ }^{25}$ Recorded by A. Panyukov and G. Savelyeva in the village of Alekseevka in Nivshera village soviet in 2000, from M.G. Gabova, born in 1932 (FF of ILLH: V1114-40).

${ }^{26}$ Recorded by A. Panyukov and G. Savelyeva in the village of Alekseevka in Nivshera village soviet in 2000, from M.G. Gabova, born in 1932 (FF of ILLH: V1114-40).

${ }^{27}$ Recorded by A. Panyukov and G. Savelyeva in the village of Nivshera in 2000, from Anisya Timofeevna Gabova, born in 1905 (FF of ILLH: V1116-57).

${ }^{28}$ Recorded by A. Panyukov and G. Savelyeva in the village of Nivshera in 2000, from A.T. Gabova, born in 1905, and L.I. Larukova, born in 1940 (FF of ILLH: V1116-61). 
${ }^{29}$ Recorded by A. Panyukov and G. Savelyeva in the village of Alekseevka in Nivshera village soviet in 2000, from M.G. Gabova, born in 1932 (FF of ILLH: V1114-40).

${ }^{30}$ Recorded by A. Panyukov and G. Savelyeva in the village of Nivshera in 2000, from A.T. Gabova, born in 1905 (FF of ILLH: V1116-57).

${ }^{31}$ Recorded by A. Panyukov and G. Savelyeva in the village of Alekseevka in Nivshera village soviet in 2000, from A.S. Gabova, born in 1925 (FF of ILLH: V1114-10).

${ }^{32}$ Recorded by A. Panyukov and G. Savelyeva in the village of Alekseevka in Nivshera village soviet in 2000, from M.G. Gabova, born in 1932 (FF of ILLH: V1114-40).

${ }^{33}$ Recorded by A. Panyukov and G. Savelyeva in the village of Alekseevka in Nivshera village soviet in 2000, from A.S. Gabova, born in 1925 (FF of ILLH: V1114-12).

${ }^{34}$ Recorded by A. Panyukov and G. Savelyeva in the village of Nivshera in 2000, from A.T. Gabova, born in 1905 (FF of ILLH: V1116-57).

${ }^{35}$ Recorded by A. Panyukov and G. Savelyeva in the village of Nivshera in 1999, from E.M. Podorova, born in 1932, and A.S. Gabova, born in 1933 (FF of ILLH: V1112).

\section{REFERENCES}

Bernshtam, Tatiana 1978. Devushka-nevesta i predbrachnaia obriadnost' v Pomor'e v XIX - nachale XX v. [The Bride and Ante-nuptial Rituals in Pomor'e in the 19th and early 20th Centuries.] In: K. Chistov \& T. Bernshtam (eds.) Russkii narodnyi svadebnyi obriad: Issledovaniia $i$ materialy. Leningrad: Nauka, pp. 48-71. Available at https://www.booksite.ru/fulltext/chistov/text.pdf, last accessed on 19 June 2019.

Bolonev \& Melnikov 1985 = Bolonev, Firs \& Mel'nikov, Mikhail (comps.) Khorovodnye $i$ igrovye pesni Sibiri. [Circle Dance and Game Songs of Siberia.] Novosibirsk: Nauka.

Kaneva, Tatiana 1998. Pesenno-igrovoi fol'klor Ust'-Tsilemskogo raiona Respubliki Komi. [Song and Game Folklore of the Ust-Tsilemsky District of the Komi Republic.] Dissertatsiia na soiskanie nauchnoi stepeni kandidata filologicheskikh nauk. Institute of Russian Literature, Russian Academy of Sciences. Available at https:// www.dissercat.com/content/pesenno-igrovoi-folklor-ust-tsilemskogo-raionarespubliki-komi, last accessed on 19 June 2019.

Krasnopolskaya, Tamara (comp.) 1977. Pesni Karel'skogo kraia. [Songs of the Karelian Region.] Petrozavodsk: Kareliia. Available at https://www.booksite.ru/fulltext/ dobrovol/text.pdf, last accessed on 19 June 2019.

Kuznetsov, Nikolai \& Lobanova, Liudmila 2014. Kollektsii komi fol'klora v estonskom fol'klornom arkhive. [Collections of Komi Folklore in the Estonian Folklore Archives.] In: Y. Krasheninnikova (chief ed.) Aktual'nye problemy sobiraniia i publikatsii fol'klornykh materialov. Sbornik nauchnykh trudov k 100-letiiu izdaniia knigi "Komi moidan kyv"ias". Syktyvkar: Institut iazyka, literatury i istorii Komi NTs UrO RAN, pp. 76-80. 
Lobanova, Liudmila \& Rassykhaev, Aleksei 2013. Narodnyi kalendar' v s. Bogorodsk Respubliki Komi. [Folk Calendar in the Village of Bogorodsk of the Komi Republic.] Zhivaia starina, No. 3, pp. 45-48.

Lobanova, Liudmila \& Rassykhaev, Aleksei 2016. Ustnye rasskazy o Tiuve: klassifikatsiia siuzhetov po zapisiam nachala XXI veka. [Oral Stories about Tyuve: Classification of Plots after the Records of the Early 21st Century.] Fol'kloristika Komi: issledovaniia $i$ materialy. Sator 17. Tartu: Nauchnoe izdatel'stvo ELM, pp. 185-222. https://doi.org/10.7592/Sator.2016.17.08.

Lobanova, Liudmila \& Rassykhaev, Aleksei 2017. Sovremennaia traditsiia pochitaniia pravoslavnykh ikon v s. Nivshera Kortkerosskogo r-na Respubliki Komi. [Contemporary Tradition of Veneration of Orthodox Icons in the Nivshera Village of Kortkerossky District of the Komi Republic.] Traditsionnaia kul'tura, No. 1, pp. 38-51.

Morozov, Igor 1998. Zhenit'ba dobra molodtsa: Proiskhozhdenie i tipologiia traditsionnykh molodezhnykh razvlechenii s simvolikoi "svad'by"/"zhenit'by". [Marriage of the Good Fellow: Origins and Typology of Traditional Youth Entertainment with the Symbolics of "Wedding"/ "Marriage".] Moscow: Labirint. Available at https:// www.academia.edu/2292246, last accessed on 19 June 2019.

Osipov, Ivan (comp.) 1941. Viser vozhsa s'ylankyv"ias da moidkyv"ias. [Songs and Fairy Tales of Vishera Vicinity.] Syktyvkar: Komi knizhnöi izdatel'stvo.

Osipov, Ivan (comp.) 1986. Viser vozhsa s'ylankyv"ias da moidkyv"ias. [Songs and Fairy Tales of Vishera Vicinity.] Syktyvkar: Komi knizhnöi izdatel'stvo.

Panyukov 2003 = Paniukov, Anatolii. Roch 'russkii' v komi traditsionnoi kartine mira. [Roch 'Russian' in the Komi Traditional World-View.] In: T. Ivanova (ed.) Lokal'nye traditsii v narodnoi kul'ture Russkogo Severa: Materialy IV mezhdunarodnoi nauchnoi konferentsii "Riabininskie chteniia-2003". Petrozavodsk: Muzeizapovednik "Kizhi", pp. 216-219. Available at https://kizhi.karelia.ru/library/ ryabinin-2003/55.html, last accessed on 19 June 2019.

Panyukov 2004 = Paniukov, Anatolii. Traditsii i sovremennost': Kharlampiev den'. (Kommentarii k videofil'mu). [Traditions and Contemporariness: Charalampus' Day (Comments to the Video).] Materialy Vtorogo Moskovskogo mezhdunarodnogo festivalia vizual'noi antropologii $i$ konferentsii "Traditsii i ob"ektiv: V poiskakh tsel'nosti". Moscow: TEIS, pp. 57-59. Available at http://visantmedia.mes.msu. ru/wp-content/uploads/2017/10/Materialy-II-MIFVA.pdf, last accessed on 19 June 2019.

Panyukov \& Savelyeva 2006 = Paniukov, Anatolii \& Savel'eva, Galina. Khramovye i zavetnye prazdniki v Komi krae (po polevym arkhivnym materialam). [Church and Sacramental Holidays in the Komi Region (on Field Archival Materials).] Paleoslavica, Vol. 14, pp. 262-286.

Savin, Viktor 1926. Musiur saiyn: Viservozhöd komi iözkostsa s'ylankyv"ias chukörtöm. [Behind the Watershed: Collecting Folk Songs across Vishera.] Komi mu, No. 9, pp. 33-41; No. 10 , pp. 35-38; No. 11, pp. 35-43.

Sorvachova \& Sakharova \& Gulyaev 1966 = Sorvacheva, Valentina \& Sakharova, Marfa \& Guliaev, Evgenii. Verkhnevychegodskii dialekt komi iazyka. [Upper-Vychegda Dialect of the Komi Language.] Syktyvkar: Komi knizhnoe izdatel'stvo. 
Teryukov 1983 = Teriukov, Aleksandr. Pogrebal'nyi obriad vymskikh i visherskikh komi. [Funeral Ceremony of the Komi of the Vym and the Vishera.] Traditsii i novatsii $v$ narodnoi kul'ture komi. Trudy IIaLI KFAN SSSR, Vyp. 28. Syktyvkar: Komi filial AN SSSR, pp. 25-31.

Zherebtsov, Liubomir \& Lashuk, Lev 1958. Staraia Vishera. [Old Vishera.] Istorikofilologicheskii sbornik, Vyp. 4. Syktyvkar: Komi knizhnoe izdatel'stvo, pp. 83-127. 